\title{
The role of higher education institutions in regional transition paths towards sustainability
}

The case of Linz (Austria)

\author{
Verena Radinger-Peer ${ }^{1} \mathbb{D} \cdot$ Gesa Pflitsch $^{2}$
}

Accepted: 18 August 2017 / Published online: 5 September 2017

(C) The Author(s) 2017. This article is an open access publication.

\begin{abstract}
The present paper investigates the role of the located Higher Education Institutions (HEIs) in the transformation towards sustainability of the city of Linz as well as the region of Upper Austria. We argue that HEIs have the potential to spur a regional transition towards sustainability via the channels of teaching, research and outreach. We furthermore take into account that organisational- and field-level drivers influence the role of HEIs within the regional transition paths towards sustainability (RTPS). We chose an explorative research design in order to give a realistic picture of the potentials and limitations of HEIs' involvement in regional transitions to sustainability. The role of the five HEIs located in the city of Linz is studied through in-depth expert interviews and a comprehensive document analysis. The investigation reveals that there is no contribution of HEIs as a whole to RTPS, but that the impact is dependent on individual highly engaged "frontrunners" enacting change and at the same time on leadership from the university management. Moreover, regulative drivers at the field-level and normative as well as cognitive drivers at the organisational-level affect HEIs' contribution.
\end{abstract}

Keywords Regional transition - Sustainability · Higher Education Institution · Organizational- and field-level drivers

V. Radinger-Peer

verena.radinger-peer@boku.ac.at

G. Pflitsch

gesa.pflitsch@geo.uni-marburg.de

1 Department of Economics and Social Sciences, Institute for Sustainable Economic Development, University of Natural Resoures and Life Sciences Vienna (BOKU), Feistmantelstraße 4, 1180 Vienna, Austria

2 Geography of Services, Communication and Innovation, Institute for Geography, Philipps-University Marburg, Deutschhausstraße 10, 35032 Marburg, Germany 


\section{Introduction}

Various political agendas, programmes and supra-national initiatives have emphasized the role of Higher Education Institutions (HEIs) in spurring sustainability and sustainable development throughout the last decades. In 1987 the Brundtland Report (WCED 1987) introduced sustainability as a concept which strives for a balanced social, ecological and economic development on different spatial scales. Launching several new principles such as:

a) increasing significance of the local and regional level,

b) public and stakeholder participation and

c) integrative, holistic approaches to regional and local challenges (Peer and Stoeglehner 2013),

the concept of sustainability confronts considerable complexity and emphasizes the need for systemic, multi-dimensional and transdisciplinary approaches. Sustainability transition research integrates technological, market and behavioural perspectives by considering the co-evolutionary development of these different elements in specific socio-technical systems (STRN 2010). The latter fulfil basic human needs such as energy supply, mobility, and housing, and are also referred to as 'sociotechnical regimes'. How to break up these path dependent structures and initiate a fundamental change in the architecture of these systems is the central question in sustainability transition research and receives increasing political attention (e.g. WBGU 2011).

Cities and regions in particular have been identified as a key for sustainable development (McCormick et al. 2013). Proximity advantages at the urban and regional levels facilitate the mobilization and integration of various actor groups and initiatives (Truffer and Coenen 2012). Empirical research has shown that sustainability transitions are highly place-specific and that some regions offer a particular favourable institutional environment for such processes (Hansen and Coenen 2015). The concept of Regional Transition Paths to Sustainability (RTPS) explains how specific institutional environments develop that favour the development of sustainable innovations and pave the way for changes in multiple socio-technical regimes (Strambach and Pflitsch 2017).

The changing political and scientific discourse has influenced the engagement of HEIs in regional development in general, and sustainable development in particular. HEIs have developed and continue to develop from their "traditional" role as mere educational infrastructure and research institutions, to "new" roles as drivers for innovation and as stakeholders in public and private partnerships, as well as in planning processes (Chatterton and Goddard 2000). This "3rd mission" depicts a broader and more adaptive role for HEIs, and their contribution to social, cultural and environmental development based on regional needs (Chatterton and Goddard 2000; Gunasekara 2006).

Lozano et al. (2015) outline seven spheres where HEIs may engage in implementing sustainability: 
1. institutional framework,

2. campus operations,

3. education,

4. research,

5. outreach and collaboration,

6. on-campus experience,

7. assessment and reporting.

Stephens et al. (2008) deepen the definition of sustainable development by not only focusing on the activities of universities, but also by taking the content of teaching and research activities into account. They apply the term "change agent" to describe four paths of university action supporting sustainable transitions:

1. providing a model of sustainable practices for society;

2. teaching students how to deal with complex problems and exercise system-thinking;

3. performing practice based research-activities; and

4. promoting and enhancing engagement between individuals and universities situated as transdisciplinary agents.

While sustainable development related educational changes as well as HEI management and campus operations are quite prominent in the literature (Lozano et al. 2015), evidence — with few exceptions (e. g. Sedlacek 2013) — is yet rare on the role of HEIs in RTPS.

The present paper aims at shedding light on the role HEIs play in the regional transformation towards sustainability using the example of Linz (Austria) and the five HEIs located therein. The two research questions of interest are:

1. what are the contributions of HEIs to RTPS via teaching, research and outreach, and

2. how is the role of HEIs within RTPS influenced by organisational- and field-level drivers?

The paper is organized in six sections. Sect. 2 elaborates the conceptual framework on the role HEIs might be able to play in RTPS by referring to state of the art scientific literature. Sect. 3 outlines the methodology of the explorative case study. Sect. 4 presents the case study of Linz and the located HEIs, and gives a concise overview of the transition towards sustainability in the city of Linz as well as the region of Upper Austria. In Sect. 5 the results of the empirical investigations are presented and are further discussed in Sect. 6, taking into account the existing literature. The final section concludes the main findings.

\section{Conceptual framework-Regional transition paths to sustainability and the role of HEIs}

It has recently been highlighted that socio-technical transition processes are strongly influenced by the territorial institutional environment in which they take place (Co- 
enen et al. 2012; Truffer and Coenen 2012). From a regional perspective, it has to be considered however that a transition to sustainability encompasses the implementation and integration of transformations in multiple socio-technical regimes. Introducing the concept of RTPS, Strambach and Pflitsch (2017) argue that regional transitions are based on more complex dynamics than transitions of specific sociotechnical regimes due to the co-evolution of their institutional environments over time and the interdependencies resulting from them. The concept of RTPS therefore refers to recent approaches from Evolutionary Economic Geography (EEG) that allow a more differentiated view on path dependent developments, focusing in particular on how actors at the micro-level use the plasticity of the regional institutional environment to enact change (Boschma and Martin 2010; Strambach 2010, Strambach and Halkier 2013; Trippl and Tödtling 2013). Empirical studies show that at the regional level actors initiate more general institutional and organisational changes that lay the foundation for changes in multiple socio-technical regimes and thematic areas. Over time, incremental changes can this way lead to a more fundamental change in direction of a regional path towards sustainability (Rohracher and Späth 2014; Strambach and Pflitsch 2017).

Different elements necessary for a socio-technical transition including actors, knowledge, materials, power etc. are usually spread over various geographical scales (Murphy 2015). Therefore Truffer and Coenen (2012, p. 11) have pointed out that: “(...) a critical examination of transition spaces would not stop at the administrative borders of territorial units (regions, nations) but would require attention for spatial dimensions and implications of sustainability transitions 'wherever they may lead'." This is based on a relational understanding of space, in which territorial scales are constituted through actor relations and not through simple geographical hierarchies (Coenen et al. 2012; Rohracher and Späth 2014). Hence in a regional transition actors may interact on multiple geographical scales, leading to a momentum of "interlocalization" (Geels and Deuten 2006), that is, "a point in the transition when formerly local actors are able to exert greater influence on a regime as the scope and extent of their influence consolidates and institutionalizes" (Coenen et al. 2012, p. 975). In other words, agency and particular conditions enable the interventions by individual actors to trigger more structural evolution (Genus and Coles 2008; Gibbs 2006).

Arbo and Benneworth (2007) pinpoint that a significant part of HEIs' regional potential lies in the fact that they are often not purely regional bodies but are multiscalar in nature, integrating the global, national and regional scale. They localize elements of both, "local nodes" and "global networks" (Späth and Rohracher 2012). Thus HEIs are expected to fulfil a bridging and brokering function between international research communities and the needs of regional stakeholders for tailormade knowledge.

In a more general understanding, the model of the "engaged university" attempts to conceptualize the comprehensive role HEIs may play for their location region, thus going beyond mere recognition of economic impacts-as argued by the Regional Innovation System Model as well as the "entrepreneurial model"-of HEIs activities. The "engaged university" characterizes HEIs as active "animateurs" (Shiri et al. 2012), which are capable of providing tailormade solutions to region-specific 
challenges and problems (e.g. urban development, transport, health, sustainable development). Also the term "change agent" (Stephens et al. 2008) raises the expectation that HEIs have the potential to take agency and thus trigger institutional and organisational changes in the regional path. This is facilitated through the channels of teaching, research and outreach.

At the same time, we argue that the HEI-region interface is highly context- (Peer and Penker 2016) and place-specific, hence, HEIs will not shape RTPS autonomously but are influenced by and depend on their local and regional environment. We propose a conceptual framework that combines two perspectives:

1. the contribution of HEIs to RTPS via the different channels of "Teaching", "Research" and "Outreach" and

2. the drivers influencing the roles of HEIs in RTPS, thus taking into account the place-specificity of the regional transition path.

In doing so we distinguish between field-level and organisational-level drivers.

\subsection{Contribution of HEIs via different channels}

Teaching. Sustainability might be integrated as theoretical content in different lectures or provide the starting point of practical student projects. New didactic methods, such as service learning, or organisational settings, such as inter- or transdisciplinary seminars, can be implemented. While a theoretical consideration of sustainability issues helps to raise awareness, practical student projects in collaboration with regional stakeholders can have a direct impact on the regional transition path. Moreover, new study programmes might be initiated which have their inception in specific regional sustainability challenges and which enable the combination of existing disciplinary contents in order to deal with complex sustainability challenges (Wickson et al. 2006). Teaching activities can be seen as an important driver of longterm institutional change in the region, as graduates and their awareness for sustainability represent a multiplier and possess the capacity to deal with such complex challenges. This process might be accelerated through additional vocational training courses or customized education programmes that are tailored to specific regional needs (Peer and Stoeglehner 2013).

Research. Research on sustainability might be conducted in individual disciplines or in the context of transdisciplinary research platforms that integrate researchers from different disciplines as well as practitioners. Sustainable transdisciplinary research differs from multi- and interdisciplinary approaches through its strong problem focus, evolving methodologies that are tailored to the specific problem under investigation and collaborative knowledge generation between researchers and stakeholders-not only in the problem solution phase but already in the stage of problem definition (Radinger-Peer et al. 2015; Wickson et al. 2006). Compared to co-research and cooperative research projects, all project members work together on all aspects of the project and not in parallel on different aspects, which are then synthesized at the end (Hord 1986). This enables environmental and social problems to be approached from a systemic perspective that is not obstructed by disciplinary 
knowledge boundaries (Russell et al. 2008). As a result, transdisciplinary projects are much more likely to generate practical knowledge directly applicable to the region.

Outreach. Outreach builds on the two former roles of the HEI. Such activities include spontaneous or occasional encounters of actors as well as more frequent and broad-based interactions with their regional environment. More permanent forms of association enable trust building and foster the development of social and cognitive proximity between actors (Coenen et al. 2012). Outreach activities may be passive, active, or proactive. A passive role means that HEIs (re)act on demand (for e. $g$. expertise, external consultation, presentations), while an active role subsumes the initiation of new platforms and discourses in the region, (voluntary) participation in advisory boards or also political engagement. Another contribution could be the formation of networks and alliances with key actors both inside and outside the region in order to influence political decision processes that affect the RTPS and acquire resources such as financial support for pilot projects in the region. In a proactive role, HEIs realize their brokering and bridging function, thus utilizing their international networks to serve the regional need or even take agency and set the agenda.

\subsection{Organisational and field level influences on the role of HEIs in RTPS}

HEIs are loosely structured organisations, whose sub-units and individual members interact on multiple scales and are influenced by regulative, normative and culturalcognitive drivers from the organisational- as well as field-level. The "field" in this understanding comprises the local, regional but also national HEI-related environment. The latter is especially interesting because HEIs in Austria, their legal framework and financing are a competence of the nation state.

Internal rules, strategies, mission statements and guidelines influence the behaviour of individuals because they seek the attendant rewards or wish to avoid sanctions (Scott 2001). On the field level, regulative mechanisms entail first of all university and higher education legislation, funding organisations and programmes, policy strategies, and programmes in adjacent fields such as regional, science and innovation policy, which may exert coercion or offer incentives.

Normative drivers entail both values and norms. While some values and norms are applicable to all members of the collective body, others apply to selected types of actors or specified social positions. Hence members of the rectorate or department heads might be confronted with the expectation to act as role models and contribute in various ways to the RTPS. This includes also the self-perception of the role of the HEI and its communication towards HEIs members. Norms and values may also be operationalized as certifications, awards or accreditations.

Cultural-cognitive drivers focus on the role of ideas, beliefs and assumptions. Taken-for-granted assumptions are among the most powerful drivers in the interaction and debate among different types of stakeholders (Colyvas and Powell 2007). Cultural cognitive elements entail, for example, routines in the interaction with regional stakeholders. We point out that this theoretical separation of the different 
driving mechanisms might not be found to reflect reality, where boundaries may blur.

\section{Methodology}

The HEIs in Linz are perceived as being among the most regionally engaged throughout Austria (see also Goldstein et al. 2016). It was therefore of interest to the authors if these HEIs also play a significant role in RTPS. A further reason for choosing the city of Linz and the region of Upper Austria as a case is their transition from an industrial city and region towards an Austrian-wide leader of transition towards sustainability. They have been the first throughout Austria in various sustainability related fields e. g. first to join the ICLEI-Local Governments for Sustainability Initiative, first province with a sustainability concept and strategy, first diocese in Linz powered by $100 \%$ green electricity, first province to transform the energy system. The question to what extent the regional HEIs contributed to these processes was open from the beginning. Although we limit our investigations to the case of Linz, we aim towards deducing some general mechanisms which shape the role of HEIs in RTPS. This explorative research design was chosen in order to give a realistic picture of the potentials and limitations of HEIs' involvement in regional transitions to sustainability. The latter is particularly important considering the high demands placed upon HEIs from the political side.

The case study is based on eight in-depth interviews with actors at the university as well as key stakeholders in the region (see Table 1). A snowball-sampling technique helped to identify all relevant actors for the purpose of this study. It consisted on the one hand of the investigation of historical documents to reconstruct the RTPS and the actors involved. On the other hand the rectors of the respective HEIs were contacted and recommended us to the most active HEI members in this regard. A narrative interview technique was chosen in order to stimulate the interviewees to reconstruct the transition process in a chronological order and emphasize those aspects that they regarded as particularly important. The narratives were then complemented by some more specific and reflexive questions. All interviews have been transcribed and forwarded to the interviewee for approval. Afterward a comprehensive document research was conducted, in order to complement and confirm the statements in the interviews. The documents investigated range from protocols from sessions of the provincial parliament, legislative texts, political concepts and programmes (including a documentation of their genesis and the actors involved), protocols of the LA21 process in Linz, and press releases, but also university-related documents such as development plans, mission statements, the research databases and profiles of selected researchers, etc. Moreover, one of the authors has been involved in other thematically related projects in the case study region and thus already possessed contextual knowledge which was helpful for approaching the interview partners and the selection of the material of interest.

The empirical material was then analysed using inductive and deductive categories derived from the conceptual framework presented in Sect. 2. Here we follow the methodological approach of Strambach and Pflitsch (2017) to reconstruct the most 
Table 1 Presentation of the interview partners, their affiliation and role within RTPS

Role of the interview partner within their organisation

Officer of the City of Linz

Sustainability Coordinator of Upper Austria and among others in charge for the Local Agenda 21 process

Deputy Head of the Institute for Environmental Management in Companies and Regions (JKU)

Head of Institute of the Institute of Environmental Law (JKU)

Rector of the $\mathrm{PH}(\mathrm{PH})$

Former rector of the KTU and Head of the Institute Moral Theology (KTU)

Professorship for Public Management (UoAS)

Study programme manager and Head of the Institute for Design and Space (UAL)
Reasons for choosing the interview partner-connection to RTPS

Environmental Department, initiator of the membership in the ICLEI-Local Governments for Sustainability Initiative of the city of Linz as well as the Local Agenda 21 process Linz

Working for more than 20 years for the government of Upper Austria in sustainability-related initiatives, projects

Supported the establishment of the sustainability focus of the institute; very well known as member of manifold regional sustainability-related initiatives

Established sustainability as core topic in research and teaching; main organizer of the event "Austrian Days of Environmental Law"; well known in the city of Linz for sustainability-related voluntary engagement

Rector since 2005; main advocate for the participation in the ÖKOLOG network as well as the establishment of the further education programme BINE

Institutionalized sustainability in the EMAS-Eco Management and Audit Scheme during his period as rector. First to introduce sustainability as content of university lectures as well as in establishing an interdisciplinary course setting

Introduced sustainability in the study programme Public Management through various lecture as well as student projects. Well known in the city of Linz for sustainability-related projects and research focus

First to introduce lectures on sustainability in the study programme Architecture. Initiated transdisciplinary student projects on sustainable wood construction. Co-initiator of the further education programme "Sustainable wood construction", initiator of the Austrian-wide award on "sustainable wood construction"

important institutional and organisational changes in the regional transition process. We conducted a document analysis on the empirical material at hand in order to extract the contributions of teaching, research and outreach activities on the one hand and the stated drivers on the other. The interview partners were available for further questions and clarifications, and provided information on complementary documents.

\section{Case study description and research setting}

Linz, the capital of Upper Austria, has a population of 201,595 (2016), and is Austria's third-largest city. Linz is one of the main economic centres of Austria with the highest rate of employment to population. The largest sector is manufacturing, in which $17 \%$ of all employees work. Between the end of World War II and the 1970s, Upper Austria became the leading industrial region in Austria with the highest export and employment rates. Small but innovative enterprises grew to be- 
Table 2 HEIs located in the city of Linz (own illustration). (Source: uni:data 2016)

\begin{tabular}{|c|c|c|c|}
\hline HEI & $\begin{array}{l}\text { Year of } \\
\text { foundation }\end{array}$ & $\begin{array}{l}\text { Number } \\
\text { of students } \\
(2015 / 16)\end{array}$ & Faculties/Institutes \\
\hline $\begin{array}{l}\text { Johannes Kepler Univer- } \\
\text { sity Linz (JKU) (public } \\
\text { university) }\end{array}$ & 1966 & 19,406 & $\begin{array}{l}\text { Faculty of Social and Economic Sciences, } \\
\text { Faculty of Law, } \\
\text { Faculty of Technical and Natural Sci- } \\
\text { ences, } \\
\text { Medical Faculty (since 2014) }\end{array}$ \\
\hline $\begin{array}{l}\text { University of Arts and } \\
\text { Industrial Design Linz } \\
\text { (UAL) (public univer- } \\
\text { sity) }\end{array}$ & 1947 & 1186 & $\begin{array}{l}\text { Art and Education, } \\
\text { Media Design, } \\
\text { Space and Design }\end{array}$ \\
\hline $\begin{array}{l}\text { Catholic-Theological } \\
\text { Private University Linz } \\
\text { (KTU) (private univer- } \\
\text { sity) }\end{array}$ & 1978 & 463 & $\begin{array}{l}\text { Faculty of Theology, } \\
\text { Faculty of Philosophy and Arts }\end{array}$ \\
\hline $\begin{array}{l}\text { University of Applied } \\
\text { Sciences Upper Austria } \\
\text { Campus Linz (UoAS) }\end{array}$ & 2001 & 823 & $\begin{array}{l}\text { Medical Technology, } \\
\text { Applied Social Sciences and Non-Profit } \\
\text { Management, } \\
\text { Aging }\end{array}$ \\
\hline $\begin{array}{l}\text { College of Education } \\
\text { Upper Austria }(\mathrm{PH})\end{array}$ & 2007 & 3000 & $\begin{array}{l}\text { Training of teachers in the fields of ed- } \\
\text { ucational science, language education, } \\
\text { mathematics and informatics, natural sci- } \\
\text { ence, social science, economics, arts and } \\
\text { sports }\end{array}$ \\
\hline
\end{tabular}

come internationally known enterprises, e. g. Voestalpine (metal production); BMWMotorenwerk Steyr, KTM, Bomardier-Rotax, Rosenbauer (vehicle construction and suppliers); Lenzing AG, Borealis AG, AMI (chemistry and paper production).

For several decades Linz had the image as a grey industrial city. Restoration and reutilization projects of former industrial sites (e.g. Tabakfabrik) into culturally interesting locations, an economic programme which strived for a diversification of the local economy (supporting tourism and trade), as well as a comprehensive social programme have all contributed to changing the image of Linz to a culturally active and economically aspiring city. In 2009 Linz was nominated European Capital of Culture.

Various HEIs are located in Linz, ranging from public universities, private universities, and universities of applied sciences to two colleges of education (see Table 2). The Anton Bruckner Private University, the Private University College of Education of the Diocese of Linz, and the University of Applied Science for Health Professions did not enter the study due to a lack of relevance to the topic.

In the 1990s, in line with and influenced by the United Nations conference on Environment and Development in Rio de Janeiro in 1992, the city of Linz as well as the state country of Upper Austria started in parallel to elaborate on their sustainability agendas. The understanding of sustainability was a holistic one, aiming for a balanced ecological, societal and economic development and thus a high quality of life for both current and future generations. On the municipal level, the programme Local Agenda 21 (LA21) was initiated. Meanwhile, the government of Upper Austria 
took several initiatives, such as establishing the LA21 as a state-wide programme, the incorporation of sustainability into the Upper Austria Spatial Planning Act, the specification of an Energy Concept for Upper Austria as well as the elaboration of a Sustainability concept and furthermore a Sustainability Strategy for Upper Austria. "The government of Upper Austria is characterized by a strong proactive power with regard to sustainability and environmental related issues" (interview partner). The 1990s are hence characterized by a political go-ahead and a high commitment to sustainability issues.

Two types of developments can be observed from 2000 on: a thematic prioritisation on energy related issues and a shift of the sustainability agenda to the economic sphere. This resulted among other developments in the foundation of the Ecoenergy cluster (renamed into Clentech-Cluster in 2016 http://www.energiesparverband.at/ info-service/cleantech-cluster.html), a network of green energy businesses which support renewable energy and energy efficiency businesses. Subsequently, and supported by the state government, a number of other clusters have been set up, representing the Green Tech Region Upper Austria. Furthermore, the government of Upper Austria decided on a second phase of the energy concept, renaming it into "Energy 21". It comprises the targets till 2010, including an increase in energy efficiency, reduction of energy consumption, development of new energy technologies as well as support of R\&D in the field of energy. At the same time, the initial euphoria on the local level came to a halt due to a change of the political power and the consequent transformation of the LA21 process "Linzer Agenda 21" into a nonbinding process.

Within the last decade, the topic of sustainability has broadened and diffused from the environmental department to other departments of the Linz city administration, with the consequence that the undertaken activities are no longer communicated under the label of sustainability. The initiated LA21 process was altered into a smart city initiative, while the city council agreed on eco-guidelines to promote the consumption of Fairtrade goods. The "Linzer Sozialprogramm" (social programme for Linz) emphasizes the social pillar of sustainability. In addition the Local Development Concept imposes a sustainable urban development model with a focus on environmental protection and therefore "internal development before outer development" (Stadtplanung Linz 2013).

In parallel, the government of Upper Austria was the first state in Austria to adopt the Global Marshal Plan, and thus gave the sustainability discussion an economic direction. The activities of this worldwide initiative comprise, for example, consciousness-raising activities, the cataloguing of measures for communities, and trainings for companies. The most recent activities on the state level comprise the Environmental Programme Upper Austria, which was elaborated in a comprehensive transdisciplinary participatory process and adopted by the government in 2014 .

This presentation illustrates that the local as well as state government have been strong agenda setters. While the RTPS process of the city of Linz was an administrative process, initiated and conducted by the department for environmental affairs, the government of Upper Austria tackled sustainability and its challenges from a transdisciplinary perspective, thereby involving numerous stakeholders from the beginning on. While there is a clear emphasis on the ecological and, to a lower 
extent, the economic pillar of sustainability at the regional level, this cannot be confirmed for the city level. Another interesting difference is the level of self-commitment: while the government anchors sustainability in binding programmes and law, it is embedded at the city level in a more non-binding nature. The local as well as the regional process are characterized by numerous institutional and organisational changes shaping the respective transition path (see also Appendix).

\section{Results}

In accordance with the conceptual framework, the result section is split up into two main chapters, investigating on the one hand the role HEIs play in RTPS via teaching, research and outreach activities, and on the other hand the organisationaland field-level drivers influencing these roles.

\subsection{The role of HEIs in RTPS via teaching, research and outreach}

The investigation of the channel "teaching" reveals that only the JKU offers whole study programmes with a clear focus on sustainability: namely the master programme "Operational and Regional Environmental Management" with its respective specializations, the specialization Environmental Law within the study programme Law as well as the bachelor programme "Economic Law" and the further education programme "Energy Management" (see Table 3). Nevertheless the topic of sustainability enters numerous lectures also within the other HEIs, ranging from "Good governance", "Ecological sustainability in moral theology", "Solar architecture", and "Fashion and Sustainability", just to mention a few (www.jku.at (Johannes Kepler University Linz 2017); https://www.fh-ooe.at/campus-linz/ (University of Applied Sciences Upper Austria Campus Linz 2017); https://ph-ooe.at/ (University College of Education Upper Austria 2017); http://www.ufg.ac.at/ (University of Arts and Industrial Design Linz 2017); http://ku-linz.at/ (Catholic-Theological Private University Linz 2017)). "As sustainability is multidimensional in nature, there are various topics which may be assigned to this concept" (interview partner). Furthermore, practical student projects with a clear focus on sustainability are conducted, mainly at the UoAS Linz (study programme Public Management), and the UAL (Institute for Space and Design) (e.g. concepts for inter-municipal cooperation, concept to counter youth out-migration of rural communities, design for regional wood construction projects, urban renewal and development projects). They are often implemented in inter- and transdisciplinary settings with representatives from the public administration, local businesses, regional management, the local population or representatives from various chambers. All of the interviewees stated that they have strong personal networks, which make these kinds of transdisciplinary student projects possible. Due to its organisational characteristics and founding idea, the UoAS in particular has a strong focus on bridging teaching content and regional practical demand. All of the investigated HEIs point out that the students and their awareness for the topic of sustainability are important multipliers at the local and regional scale. This becomes especially important as-according to information pro- 
Table 3 Teaching, research and outreach activities towards RTPS of the investigated HEIs

\begin{tabular}{|c|c|c|c|}
\hline HEI & Teaching & Research & Outreach (selection) \\
\hline JKU & $\begin{array}{l}\text { "Environmental Law" } \\
\text { (Austrian-wide unique } \\
\text { specialization within } \\
\text { the study program law) } \\
\text { Graduate programme } \\
\text { "Energy management" } \\
\text { "Future Lectures" } \\
\text { series } \\
\text { Study programme } \\
\text { "Environmental-, Re- } \\
\text { source- and Quality- } \\
\text { Management" } \\
\text { Further education } \\
\text { programme "Energy } \\
\text { Management" }\end{array}$ & $\begin{array}{l}\text { Institute of Environmental Law: } \\
\text { research on diverse fields of } \\
\text { environmental law, e. g. legal } \\
\text { frameworks of carbon capture } \\
\text { and storage, hydropower in } \\
\text { Natura } 2000 \text { areas, light pollu- } \\
\text { tion, legal issues of the energy } \\
\text { certificate. } \\
\text { Institute of Environmental Man- } \\
\text { agement in Companies and } \\
\text { Regions: research in the field } \\
\text { of climate change, environ- } \\
\text { mental protection, renewable } \\
\text { energy, environmental technol- } \\
\text { ogy, sustainable technologies, } \\
\text { sustainable economic activity, } \\
\text { and environmental politics. } \\
\text { Energy Institute: applied re- } \\
\text { search in the field of energy law, } \\
\text { energy economics as well as } \\
\text { energy technology } \\
\text { Students master thesis in the } \\
\text { mentioned research fields }\end{array}$ & $\begin{array}{l}\text { Public event series "Days of } \\
\text { Environmental Law" } \\
\text { Public event series "Ed- } \\
\text { ucation for sustainable } \\
\text { development" } \\
\text { Participation in the LA21 } \\
\text { working group on air, cli- } \\
\text { mate and energy of the city } \\
\text { of Linz } \\
\text { Participation in the elabora- } \\
\text { tion of the regional energy } \\
\text { concept "Energy } 21 \text { " } \\
\text { Participation in the elabo- } \\
\text { ration of the Environmental } \\
\text { Programme Upper Aus- } \\
\text { tria } 2030 \text {, Upper Austrian } \\
\text { Energy concept, Upper } \\
\text { Austrian Future academy } \\
\text { and further current political } \\
\text { discussions }\end{array}$ \\
\hline KTU & $\begin{array}{l}\text { Ecological sustainabil- } \\
\text { ity in moral theology } \\
\text { Interdisciplinary lec- } \\
\text { ture on sustainability in } \\
\text { arts and moral theology } \\
\text { Further education } \\
\text { opportunities in sus- } \\
\text { tainability issues for } \\
\text { members of the KTU }\end{array}$ & $\begin{array}{l}\text { Research projects on sustainable } \\
\text { lifestyle, sustainable nutrition } \\
\text { and food, regionalisation and } \\
\text { greening of agriculture etc. }\end{array}$ & $\begin{array}{l}\text { Former rector is active as } \\
\text { environmental spokesper- } \\
\text { son of the dioceses Linz } \\
\text { (supported the dioceses be- } \\
\text { coming } 100 \% \text { powered by } \\
\text { green electricity) } \\
\text { Initiatives like "abandon the } \\
\text { car", fair trade days etc. }\end{array}$ \\
\hline $\mathrm{PH}$ & $\begin{array}{l}\text { Sustainability as inher- } \\
\text { ent principle of most } \\
\text { lectures } \\
\text { BINE-further edu- } \\
\text { cation programme for } \\
\text { teachers on innovations } \\
\text { in education for sus- } \\
\text { tainable development }\end{array}$ & Research pillar in development & $\begin{array}{l}\text { Participation in the } \\
\text { ÖKOLOG network } \\
\text { Cooperation with the Aus- } \\
\text { trian Youth Red Cross and } \\
\text { Austrian Students Union for } \\
\text { the integration of refugees } \\
\text { via cultural and language } \\
\text { courses } \\
\text { Projects with Ars Electron- } \\
\text { ica (e. g. museum of the } \\
\text { future) on the elaboration of } \\
\text { an OTELO-open technol- } \\
\text { ogy lab }\end{array}$ \\
\hline
\end{tabular}

vided by the interview partners - the majority of the students enter the labour market in Linz or Upper Austria after their studies.

With regards to research, sustainability is on the agenda of selected institutes of the investigated HEIs, for which it is a basic principle or even taken for granted, or as one interview partner states "sustainability is our umbrella brand, under which various thematic specialisations are subsumed". The investigation of the HEIs' research 
Table 3 Teaching, research and outreach activities towards RTPS of the investigated HEIs (Continued)

\begin{tabular}{|c|c|c|c|}
\hline HEI & Teaching & Research & Outreach (selection) \\
\hline UoAS & $\begin{array}{l}\text { Sustainability is an- } \\
\text { chored as topic in } \\
\text { various lectures in } \\
\text { the study programme } \\
\text { "Public Management": } \\
\text { "Public Governance", } \\
\text { "Good governance", } \\
\text { "Regional development } \\
\text { and inter-municipal } \\
\text { cooperation" } \\
\text { Transdisciplinary study } \\
\text { projects }\end{array}$ & $\begin{array}{l}\text { Research in the field of partic- } \\
\text { ipatory community planning, } \\
\text { good governance; strategies to } \\
\text { encounter out-migration from } \\
\text { rural communities; labour mar- } \\
\text { ket integration of people with } \\
\text { disabilities; inter-communal } \\
\text { cooperation in various fields } \\
\text { (infrastructure, education, child- } \\
\text { care) } \\
\text { Transdisciplinary research } \\
\text { settings } \\
\text { Master thesis in cooperation } \\
\text { with regional stakeholders (e. g. } \\
\text { sustainable transport concepts, } \\
\text { sustainable location develop- } \\
\text { ment) }\end{array}$ & $\begin{array}{l}\text { Event series "Public man- } \\
\text { agement impetus" } \\
\text { Fair Trade Days } \\
\text { Transdisciplinary coopera- } \\
\text { tion (various associations, } \\
\text { different departments of the } \\
\text { government Upper Aus- } \\
\text { tria, Austrian Chamber of } \\
\text { Labour, Austrian Chamber } \\
\text { of Commerce, Regional } \\
\text { management) }\end{array}$ \\
\hline UAL & $\begin{array}{l}\text { Lectures "Solar archi- } \\
\text { tecture","Ecology", } \\
\text { "Fashion and sustain- } \\
\text { ability" } \\
\text { Student projects on } \\
\text { sustainable wood tim- } \\
\text { ber construction } \\
\text { Further education } \\
\text { programme "Überholz" } \\
\text { (sustainable timber } \\
\text { construction) }\end{array}$ & $\begin{array}{l}\text { Research with focus on regional } \\
\text { sustainable timber construction } \\
\text { Project "ins Blaue" on the elab- } \\
\text { oration of a sustainable fashion } \\
\text { label } \\
\text { Endowment professorship on } \\
\text { "Sustainable and Spatial Tac- } \\
\text { tics" }\end{array}$ & $\begin{array}{l}\text { Initiation of the Upper } \\
\text { Austrian Wood construction } \\
\text { price; } \\
\text { Public lectures, presenta- } \\
\text { tions and media work (local, } \\
\text { regional and national) to } \\
\text { raise awareness for the topic } \\
\text { "sustainability" in archi- } \\
\text { tecture, construction and } \\
\text { design }\end{array}$ \\
\hline
\end{tabular}

$J K U$ Johannes Kepler University Linz, KTU Catholic Theological Private University, PH College of Education, UoAS University of Applied Sciences Upper Austria, UAL University of Arts Linz

activities reveals that following Rio in 1992 there was a strong focus on environmental issues as well as on sustainability in a holistic sense, whereas in the last decade a separation into the topics of energy, demography, climate change etc. has taken place (see also research documentation of the JKU: http://www.jku.at/content/e263/ e16099/e16086/ (Johannes Kepler University Linz 2017); UAL: https://ufgonline. ufg.ac.at/ufg_online/; (University of Arts and Industrial Design Linz 2017) UoAS: http://research.fh-ooe.at/ (University of Applied Sciences Upper Austria 2017)). The research topics covered in the investigated HEIs are manifold, ranging from climate change, environmental technology, energy law and economics to sustainable lifestyle, sustainable nutrition and food, sustainable transport concepts, etc. (see Table 3). Although inter- and transdisciplinary research settings are taken for granted in all of the investigated institutes, no institutionalized transdisciplinary research platform has been set up so far. Contacts to partners from the public policy arena, industry and the regional economy, and other regional stakeholders are informal and selective, and strongly dependent on each individual's networks.

Interestingly, the investigated institutes vary in the degree of regionalism of their research focus and partners. While an interview partner from JKU points out that "unfortunately often the results from basic research projects do not find their way 
into practice", interviewees from the UoAS emphasize the impact through interand transdisciplinary research settings with local and regional stakeholders. The Energy Institute at the JKU shows a high local and regional focus regarding research projects as well as partners (http://www.energieinstitut-linz.at/v2/projekte/ (Energy Institute 2017)). This is also true for the Institute of Environmental Law, the Institute of Environmental Management in Companies and Regions at the JKU as well as the UoAS. The KTU and the UAL, on the other hand, show in general a low degree of research activities with a regional focus. The research and student projects throughout Upper Austria in the field of sustainable wood construction conducted by UAL are a notable exception. The PH as a rather young HEI is still in the development phase of its research pillar. It was pointed out that a strong regional focus does not necessarily conflict with the distinct national and international perspective of the HEI. The investigated HEIs confirm that contacts through teaching and research with stakeholders on the regional level outnumber the contacts with the local level, especially the city government of Linz.

When it comes to outreach activities, all of the investigated HEIs are very active: ranging from annual public events (Austrian Days of Environmental Law, Public Management Days), participation in Austrian-wide cross-organisational activities (e. g. Future Lectures), volunteer involvement (e.g. environmental spokesperson in the diocese Linz), numerous presentations and speeches, provision of expertise in regional bodies (e.g. advisory board of the Ecoenergy cluster), initiation of awards (e. g. Upper Austrian Wood construction prize) and participation in working groups (e. g. elaboration of the regional energy concept "Energy 21"). One interview partner put individual engagement in a nutshell "(...) recently we conducted a pilot study in the field of sustainable transport and e-car sharing for a regional partner, because we have been interested in the topic and considered it important, it was not important for us to receive funding for it".

Taking again into account the spatial dimension of the contribution of HEIs to RTPS via the channel of outreach, the contacts with the city government of Linz are occasional and informal, and often take place on the personal level between single individuals, rather than on the level of the organisation. While the Institute for Environmental Law as well as the UoAS and PH outline good and regular contacts to the city government Linz, other interviewees highlight that requests from the municipality level are rare. The picture is a different one for the role of the HEIs on the regional level, where all of the investigated HEIs are in ongoing collaboration and contact with departments of the state government and other organisations (e.g. Chamber of Commerce, Climate Alliance Upper Austria). "The contribution of our institute to a transition towards sustainability is more regional than local. In my perspective it is a well-known problem, that the potential in front of one's own door is not valued" (interview partner, referring to the scarce contacts to the city government). 


\subsection{Organisational and field-level drivers influencing the role of HEIs within RTPS}

The legally defined 'type' of organization influences the share of teaching versus research and the self-perception of HEIs towards their regional mission. While the focus on teaching and research is rather balanced at public universities (JKU, UAL), private universities (UAL) and UoAS have a strong emphasis in teaching as the number of students has also financial implications. The UoAS is the only type of HEI with an inherent and explicit regional mission.

On the organisational-level the university management can exert coercive power via the regulatory framework (e.g. development plan) and/or undertake voluntary activities such as mission statements, memoranda, or participate in international networks, which spur normative and cognitive change.

The Development plan is the strategic instrument of the university, outlining personnel related developments, foci of study programmes, teaching and research, as well as societal goals, following the template from the performance agreements with the national ministry (Österreichischer Wissenschaftsrat 2016). The development plans of the universities are elaborated by the rectorate and enfold a selfbinding character for the university management and a guiding normative framework for faculty members. The JKU outlines sustainability within the development plan 2006-2012 (Johannes Kepler University Linz 2009), as one component of the fields of excellence "environment/energy/sustainability" as well as "management/ economic politics/environmental law". In 2013 it is further emphasized as a main thematic focus of the excellence fields "management and innovation", "biotechnology" as well as "social systems/welfare state" (Johannes Kepler University Linz 2013). On the other hand, sustainability is not mentioned in the mission statement of the university. The UAL emphasizes and acknowledges sustainability as a thematic focus of selected teaching and research activities in the development plan 2014-2018 (University of Arts and Industrial Design Linz 2014). The UAL does not have a separate mission statement. The UoAS Upper Austria outlines in its mission statement and strategy: "Through regional and global interlinkages with economy, society, public bodies, research and education institutions we create education opportunities, innovation, knowledge and sustainability" (University of Applied Sciences Upper Austria Campus Linz 2016). Special emphasis is given to ecological sustainability. The KTU does not have a mission statement, nor a development plan. The PH as youngest HEI does not emphasize sustainability in its overall strategy, but highlights in the description of the single areas and study programmes of the PH that "sustainability is taken into account on all levels of education and further education programmes for teachers". In sum it turns out that:

a) there was/is not a continuous commitment towards sustainability throughout the last decades,

b) any attention given to these issues is not always communicated under the label of sustainability (e.g. the KTU mentions in its environmental mission statement the environmental responsibility of the KTU) and 
c) the way in which sustainability is grounded and mentioned in the investigated documents implies no obligation.

Apart from these formal frameworks several HEIs engage in voluntary activities influencing the institutional framework:

In 1996 the KTU committed itself to the environmentally friendly management and operation of the university, and-under the leadership of the rector-has bundled their activities in the field of sustainability in the EMAS (Eco Management and Audit Scheme) from 2009 on. The JKU was one of the first Austrian Universities to sign and endorse the Copernicus Charter in 1993 (Campus Sustainability Centre 2005), thereby committing themselves to featuring sustainability prominently in curricula, institutional management and service. It was in 2005 when the JKU, as part of the European University Association, signed the Graz declaration (European University Association 2005), and therewith renewed its commitment towards sustainability. The PH Upper Austria was the first to join the ÖKOLOG network. ÖKOLOG is an initiative of the Austrian Federal Ministry for Arts and Culture to support sustainability as educational content. The HEI management as well as other HEI boards exert authority and induce organisational change in form of the foundation of new university institutes, professorships or the establishment and (re-)orientation of study programmes: the rectorate of the JKU, together with the city of Linz and state government Upper Austria founded the Institute for Environmental Law in 1994 and the Institute for Environmental Management in Companies and Regions in 1998, along with respective study programmes and specializations. Another example is the endowment professorship on "Sustainability and spatial tactics" at the UAL in 2010. Managerial incentives of this kind to legitimate sustainability related activities were not found at all of the investigated HEIs. Faculty members in some of the HEIs took action or made use of the opportunities afforded by their position (e. g. as head of an institute, study programme manager). This was, for example, the case at the UOA: "I brought the topic of sustainability to the HEI. In the environment where I was working before joining the HEI it was taken-for-granted to take sustainability and its dimensions into account. Therefore, it was somehow self-evident for me to bring this topic to the HEI and implement it into the curricula in my role as study programme manager. I initiated this process 20 years ago and it was not until the last years that I have the feeling that it also reached the university rectorate" (interview partner).

Two further examples which have been already described, were certain personalities in their role as rectors have initiated institutional change, are the EMAS (Eco Management and Audit Scheme) at the KTU and the participation in the ÖKOLOG by the PH. The crucial role of individual faculty members incorporating sustainability issues into the content of their lectures, or even setting up whole courses around it, should not be underestimated. The driving mechanism evident here is a normative one: it is the personal values of faculty members as well as their personal perception of their role and position at the HEI which generates a commitment to sustainability and thereby shapes the overall role of HEIs in RTPS. "It is part of my understanding of science to bring also controversial topics such as sustainability into the public debate" (interview partner). "Numerous lectures, presentations and other types of engagement in the field of sustainability are conducted based on personal 
convictions. It is this kind of engagement which is special to researchers in the field of environmental protection and sustainability. I have seen and learned this from my former head of the institute" (interview partner). The latter statement captures another important organisational-level driver: role models. Several interview partners mentioned their mentors and former heads of institutes or departments as role models when it comes to engaging with sustainability related topics. It was also pointed out that due to the small size of institutes focusing on sustainability related issues, limited personnel and time resources are a barrier to engagement. Apart from the described normative driver, different forms of incentives may activate engagement within RTPS. Such incentives at the organisational level include awards, funding programmes, official recognition of output besides teaching and research contributions, or oral appreciation. For the investigated HEIs it is especially oral appreciation from the rectorate that was confirmed as important.

For reasons of precision we differentiate the field-level drivers into national, local as well as regional ones.

The national level exerts a strong regulative power on HEIs. That is on the one hand due to the fact that much of the relevant legislation lies within the purview of the national government (Ministry of Science, Research and Economy, Ministry of Education), as does the basic financing (except for private universities). The investigation of the respective legal basis (Universitätsgesetz 2002 (2017); Hochschulgesetz 2005 (2017); Privatuniversitätengesetz 2011 (2017); Fachhochschulstudiengesetz 1993 (2017)) revealed that only the University Law 2002 mentions "sustainable resource use" as one of the guiding principles and furthermore outlines that "universities (...) are responsible to contribute to the beneficial development of society and the natural environment". Although sustainability is therefore part of the legal framework, one interview partner states, “(...) as there are no sanctions for not taking sustainability into account, it has not yet entered all areas of the university". According to the interview partners, the performance agreements between the ministry and the universities on the one hand, as well as the national funding programmes on the other hand, exert more influence on the sustainability focus and activity of the HEIs than the legal framework. The ministry provides a general template for the performance agreements but leaves sustainability dependent on voluntary compliance.

What exerts a stronger influence are the nationwide funding programmes, specifically the FFG (the Austrian Research Promotion Agency for applied research) and the FWF (the Austrian Research Fund for basic research), but also the Austrian Climate and Energy fund - a special programme to foster research and development for sustainable energy technologies and climate. The FFG has also developed special programmes, in line with international EU programmes and agendas, with a focus on energy and environmental studies (e. g. smart city, city of the future, e-mobility, etc.). As third party funding is an important source of income for all of the mentioned HEIs (becoming even more important following the University Law 2002 (2017)), these programmes and funding schemes influence research foci and raise awareness among researchers and HEI management.

Through prizes and awards, appreciation is expressed and further awareness raised. The interview partners confirmed that such incentives have more of an indirect effect than that of a direct driver. One of the best known is the "Austrian Sustainabil- 
ity Award" (BMWF, BMLFUW 2010, 2012, 2014). The Institute for Environmental Law has received this award multiple times (2010, 2012, and 2014) for their event series "Austrian Days of Environmental Law", the project "Carbon Capture Storage-technical requirements and legal frameworks" and the project "Legal issues of the energy certificate". The PH was also nominated for this award in 2014 for their activities in the ÖKOLOG network, and also in 2016 for the further education programme "BINE". By expressing appreciation, this award aims at incentivizing HEI members, while raising awareness and legitimizing their initiatives.

At the regional level of the state of Upper Austria as well as City of Linz several driving mechanisms are rather similar to those of the national level, namely funding programmes, political strategies and agenda setting, as well as awards.

Through various activities by the government Upper Austria in the early 1990s (elaboration of a sustainability concept, Sustainability Strategy Upper Austria, programme Local Agenda 21) sustainability was activated at the state and local level. "For us the topic of sustainability became interesting in research, because it was activated by the state politics" (interview partner). An interview partner pointed out that these initial holistic attitude towards sustainability was replaced by a thematically focused one:

"While a holistic understanding of sustainability was on the agenda in the early 1990 s, the political and also scientific discourse specialized into different spheres such as energy, climate, demography etc." (interview partner).

The Government of Upper Austria influenced the research agenda, e. g. through the regional Energy concept "Energy 21" and the elaboration of "Environmental Programme 2030", as well as associated funding schemes and research contracts. "With regards research projects and funding for research projects, we are highly dependent on the demand raised by local and state politics. Most of the time we are contacted personally and asked to conduct research on a special issue. This demand also influences our research agenda" (interview partner) Furthermore the Government of Upper Austria influences forms of collaboration in an innovative way: for the two mentioned programmes, inter- and transdisciplinary working groups have been set up to jointly elaborate on measures and targets in defined areas (e.g. electricity, health, mobility). The process for the elaboration of the "Environmental Programme 2030" even entailed a broad participatory process with citizens and youth councils in addition to experts from the public, private and scientific sectors. Apart from legitimizing and awareness rising, these approaches shape regional network structures and influence future interaction and cooperation between different stakeholders. While the state government implemented incentives for HEIs to join local and regional initiatives, the city administration steered sustainability related initiatives quite autonomously.

Apart from these changes in the institutional environment, certain activities leading to organisational change within the HEIs deserve mention. That are the already mentioned foundations of the Institute of Environmental Law as well as the Institute of Environmental Management in Companies and Regions which institutionalize and legitimate of the sustainability focus at the HEIs. Again in 2001, the City of Linz and the Government of Upper Austria jointly founded the Energy Institute, an independent association that is located at the campus of the JKU. This inter- 
disciplinary research institute focusing on economic, legal and technical aspects of energy related issues is intended to support local and regional industry with cuttingedge applied research and thereby support the state-wide energy transition.

The "Upper Austrian Award for Environment and Nature" which was renamed into "Upper Austrian Award for Environment and Sustainability" in 2012 is intended to function as a indirect driver for HEI's activity in RTPS. Appreciation is also expressed face to face or through financial support of certain activities (e.g. the City of Linz financially supports the journal "Environment and Law" from the Institute of Environmental Law and certain events).

\section{Discussion}

The present paper elaborates on the questions of:

1. which roles HEIs play in the regional transformation towards sustainability via the channels of teaching, research and outreach, and

2. by which organisational- and field-level drivers these roles are influenced.

The results underline that the investigated HEIs have not been engaged in RTPS in a holistic organisational sense, but a selected number of institutes and individual HEI members are active, thereby confirming the multilevel structure (Arbo and Benneworth 2007) of these highly complex silos (Denman 2009) with numerous autonomous subunits.

The contribution of teaching activities to RTPS is seen in consciousness raising, legitimization and provision of knowledge for regional needs. Activities to incorporate sustainability into teaching are highly dependent on the bottom-up motivation of single faculty members and the top-down consolidation of the university management. While a theoretical incorporation of sustainability into teaching contents may raise awareness, the investigations reveal that a certain degree of institutionalization (Olsen 2007), e. g. in terms of whole study programmes as well as student projects and final thesis on sustainability issues in cooperation with regional actors have longterm effects on RTPS. HEIs are learning organisations (Benneworth et al. 2009) and, as such, an increased institutionalization of sustainability can be confirmed as also being a result of the interaction with the regional environment. The highest impact is attributed to the graduates and their function as regional multipliers.

In contrast, research activities in the field of sustainability are strongly affected by national and international funding programmes and their respective focus as well as contract research placed by regional actors. In the case of Linz research activities have been transformed from a holistic approach in the 1990s to a thematically specified one (especially on renewables and climate change). The contribution of research to RTPS is dependent on the regional focus of the research endeavour and, above all, the correspondence of research foci with local and regional demands (Chatterton and Goddard 2000). The members of the investigated institutes show strong personbound networks with policy makers and other stakeholders at the regional and local levels. Through their relationships and networks they are 'well placed' to encourage support (Eisen and Bartlett 2006) which has allowed the elaboration of expertise in 
the field of sustainability and the development of a dedicated research focus. This includes personal contacts to the municipal council, to the government of Upper Austria, as well as to industry partners and other research institutions outside the region.

Their relational proximity influences their behaviour at a number of different scales (Coenen et al. 2012) and shapes also the opportunities they are offered. In line with Saxenian (2000) we reveal that these relationships are not purely economic: culture and trust are also important facilitators of cooperation.

Furthermore, the absorptive capacity of the regional environment and the research approaches affect the contribution of research towards RTPS. Inter- and transdisciplinary research settings anchor research projects and support the implementation of results. This has also been confirmed for applied research versus basic research projects (Fritsch and Slavtchev 2010). Overall the contribution of research to RTPS can be seen in the shaping of public opinion and discourse, scientific substantiation of political strategies, expert know how, and concrete scientific contributions to process or product innovations (e.g. in the field of renewables).

With respect to outreach activities, mostly those HEI members who are already active in research and teaching also engage in this field, showing a high amount of voluntary and private engagement in fostering RTPS. This engagement cannot be reduced exclusively to their personal interest in the topic but also has the strategic dimension of ensuring future funding and contract research or taking agency to trigger structural change (Genus and Coles 2008). Most of the time outreach activities are demand driven and based on invitations from respective regional stakeholders. Exceptions are the initiation of event series at the HEI (e. g. Austrian Days of Environmental Law), the taking over of honorary appointments (e.g. environmental spokesperson for the Dioceses), and the initiation of awards (Award for sustainable wood construction), where individual HEI members took the lead. The value of outreach activities lies in consciousness and awareness raising, legitimization of sustainability issues in the region, support of political strategies as well as serving as role models for other HEIs and HEI members.

Overall, the contribution of HEIs in Linz to RTPS via teaching, research and outreach is manifold but also fragmented. We agree with Denman (2009) that many of the efforts for transitions towards sustainability address only one or two aspects, thus focusing on the institutional framework, education, teaching, campus operation, outreach or assessment and reporting.

One reason for this is the role of the HEI management: while organisational changes (such as the foundation of institutes, study programmes, professorships) which set the frame for further sustainability-related activities have been implemented, we observe a lack of leadership. Goldstein et al. (2016), Sedlacek (2013) and Hamann and April (2013) emphasize the crucial role of leadership to promote sustainability within the HEI, but also within the regional context. Leadership of the university management in sustainability transitions entails visioning, laying out longterm system-level goals and objectives, and establishing the structure and context for social change in a strategic way (Stephens and Graham 2010). Although several rectors engage themselves in sustainability related activities in the region, sustain- 
ability as a leading principle has not yet found its way-with few exceptions-into the mission statements, development plans or strategies of the investigated HEIs.

A further reason for the fragmented contribution of the HEIs towards RTPS is the high level of person-boundedness of the depicted activities, and, at the same time, the rather low level of institutionalization, respectively temporal institutionalization. This raises the question of whether these activities would continue if the relevant individuals were to leave the HEI.

As elaborated in detail in Sect. 5 a strong influence on RTPS is exerted by single HEI individuals who have taken agency afforded by their particular position at the HEI. Agency provides for a consideration of the role of power in institutional processes, thus referring to an actor's ability to have some effect on the social world, altering the rules, relational ties or distribution of resources (Scott 2001). They have furthermore also been role models for engaging in sustainability-related activities in the local and regional context. It is their intellectual engagement with environmental and broader sustainability issues, as well as their worldviews and beliefs (Barlett 2008), which have influenced other members of the HEI. Furthermore, through their relationships and networks they have been able to provide necessary financing which has allowed the elaboration of expertise in the field of sustainability and the development of a dedicated research focus. These committed individuals, so called 'champions' (Hoover and Harder 2015), or 'frontrunners' (Brown et al. 2013), are central to institutional and organisational changes towards sustainability (Wright and Wilton 2012).

In sum the investigated HEIs show manifold contributions via teaching, research and outreach activities, which are mainly influenced by highly engaged single individuals and their role model effect, regional/national and international funding programmes as well as the place-specificity of their region. While our investigation reveals that leadership of the HEI management in sustainability related issues is not a mandatory prerequisite for HEI members to become engaged, it might enhance the degree of engagement within various disciplines and institutes at the HEI. In the lack of leadership of the investigated HEIs we see one reason for their fragmented contribution, for the continuing reservations between the different types of HEIs and, consequently, the lack of interdisciplinary collaborations between members of HEIs located in Linz and focusing on sustainability. Overall we observe that the role of the investigated HEIs towards RTPS is rather a responding than active one. While in regions with poorly developed governance structure and weak regional leadership "it is often necessary for HEIs to (...) set the development agenda" (Goddard and Puukka 2008, p. 21) in our case the state government set a strong top-down initiative what regards the research agenda, funding programmes, as well as the role of the HEIs within RTPS.

\section{Conclusion}

The present paper revealed that HEIs have the potential to enact institutional and organisational change and thus spur a regional transition towards sustainability via the channels of teaching, research and outreach. Activities to incorporate sustainability 
into teaching are highly dependent on the bottom-up motivation of single faculty members and the top-down consolidation of the university management. Research activities in contrast are shaped by field-level drivers such as national and international funding programmes as well as regional allocation of contract research. We revealed that those individuals who are engaged in respective research and teaching activities are also active in outreach activities within RTPS. The latter is not part of the core functions of the HEI but an important channel to raise awareness for one's one research and contributes to political and public opinion forming. Especially outreach activities have proven to have also a strategic dimension of ensuring future funding or taking agency to trigger structural change. Although the contribution of the HEIs in Linz to the RTPS over time is remarkably, their role can be regarded as rather responsive than active. Subsequently we would like to summarize how our findings can be transferred to other regions.

First and more generally, the case underlines the place specificity of the role of HEIs in RTPS which is shaped by the historically developed governance structures in the region and the already existing relationships between HEIs and their regional environment. It also becomes apparent that the mix of HEIs in the region influences their role in RTPS. It might be that in regions with only one main HEI the activities can be bundled and coordinated more easily. In regions with many HEIs, the role of HEI is spread over different actors. While this might result in a loss of efficiency, it might also be conducive for the process, as different types of HEIs set different kinds of impulses.

Second, we can generalize from our findings that there is no role played by HEIs as a whole in RTPS, but as a multi-level organisation, different spheres within the HEI ranging from HEI management to individual researchers have become active. So called 'champions' and 'frontrunners' are characterized by holding key positions at the HEI (e.g. rector, study programme manager, head of institute) which allow them to take agency and precipitate organisational and institutional change within the HEI. Apart from their position, their personal multi-scalar networks and their relational proximity to public and private stakeholders influences the awareness of the region for the contribution HEIs can make.

Third, we can deduce that the role of HEIs in RTPS has to be regarded as the result of the dynamic interplay of HEIs, regional and state level actors. It becomes apparent that, regardless of the specific regional circumstances, no one actor can initiate this process on its own. We also revealed that both bottom up activities (as in the case of the universities) as well as more top down approaches (as in the case of the region) can sucessfully trigger change within the university or the region. An alignment of both initiatives as well as strengthening of interdisciplinary cooperation among the various HEIs seems to be ideal to realize the full potential of HEIs in RTPS.

Fourth and finally, a certain level of institutionalization enables trust building and the development of relational proximity. We hypothesize that in order to take over a more active role within RTPS HEIs have to fully exploited their potential as brokering and bridging organisations. That entails their potential for bringing together various stakeholders in institutionalized transdisciplinary settings, which 
would allow HEIs to enter into a continuous process of dialogue instead of providing their expertise sporadically and on demand.

In order to deepen these results, it would be necessary to conduct more comparative research in the future. We think that the combined analysis of organizational and field level drivers provides a good starting point for systematic comparisons with other regions.

Acknowledgements Open access funding provided by Austrian Science Fund (FWF). We thank three anonymous reviewers for their thorough and helpful comments.

Open Access This article is distributed under the terms of the Creative Commons Attribution 4.0 International License (http://creativecommons.org/licenses/by/4.0/), which permits unrestricted use, distribution, and reproduction in any medium, provided you give appropriate credit to the original author(s) and the source, provide a link to the Creative Commons license, and indicate if changes were made.

Funding Project funded by the Austrian Science Fund (FWF), Project number: T761-G27, Project title: "Higher Education Institutions (HEIs) - Region collaboration. How HEIs and local and regional actors 'learn' to interact and collaborate effectively in knowledge-based problem-solving activities-a crosscountry analysis of European Case Studies."

\section{Appendix}

Table 4 Institutional change in the located HEIs

\begin{tabular}{|c|c|c|}
\hline No & Year & Description \\
\hline 1 & $1993-\mathrm{JKU}$ & Copernicus Charter is signed \\
\hline 2 & $1996-\mathrm{KTU}$ & $\begin{array}{l}\text { Commitment of the university management to an environmentally } \\
\text { friendly operation of the HEI }\end{array}$ \\
\hline 3 & 2003-UAL & $\begin{array}{l}\text { Upper Austrian Timber Award is initiated on the initiative of a profes- } \\
\text { sor from the University of Arts Linz }\end{array}$ \\
\hline 4 & 2005-JKU & Graz declaration is signed \\
\hline 5 & 2007-UoAS & Transition from Public Management to Public Governance in teaching \\
\hline 6 & 2009 & EMAS process is initiated \\
\hline 7 & $2010-\mathrm{KTU}$ & $\begin{array}{l}\text { The environmental guidelines of the KTU are decided by the faculty } \\
\text { council }\end{array}$ \\
\hline 8 & $2010-\mathrm{JKU}$ & $\begin{array}{l}\text { The Institute for Environmental Law, JKU is awarded the Austrian } \\
\text { Sustainability Awards multiple times }\end{array}$ \\
\hline 9 & $2010-\mathrm{PH}$ & Austrian Sustainability Award ort he ÖKOLOG initiative \\
\hline 10 & $2011-\mathrm{KTU}$ & $\begin{array}{l}\text { The diocese is powered to } 100 \% \text { by green electricity due to the en- } \\
\text { gagement of the environmental spokesperson of the diocese, who is } \\
\text { professor and former rector of the KTU }\end{array}$ \\
\hline 11 & 2014-UoAS & $\begin{array}{l}\text { The mission statement of the HEI states a commitment to ecological } \\
\text { sustainability }\end{array}$ \\
\hline 12 & $2016-\mathrm{PH}$ & $\begin{array}{l}\text { Austrian Sustainability Award for BINE_Education for Sustainable } \\
\text { Development }\end{array}$ \\
\hline 13 & 2016-UoAS & Audit as family-friendly HEI \\
\hline
\end{tabular}

JKU Johannes Kepler University Linz, KTU Catholic Theological Private Universiy, PH College of Education, UoAS University of Applied Sciences Upper Austria, UAL University of Arts Linz 
Table 5 Organisational change in the located HEIs

\begin{tabular}{|c|c|c|}
\hline No & Year & Description \\
\hline 1 & $1994-J K U$ & Institute for Environmental Law is founded \\
\hline 2 & 1994 -JKU & $\begin{array}{l}\text { The event "Austrian Days of Environmental Law" takes place for the } \\
\text { first time }\end{array}$ \\
\hline 3 & 1996 - JKU & Foundation of the Association of the Institute for Environmental Law \\
\hline 4 & $1998-\mathrm{JKU}$ & $\begin{array}{l}\text { Institute for Environmental Management in Companies and Regions is } \\
\text { founded }\end{array}$ \\
\hline 5 & 1999—JKU & $\begin{array}{l}\text { Specialization Environmental Law as part of the study programme Law } \\
\text { at the JKU is offered (as first Austrian-wide) }\end{array}$ \\
\hline 6 & 2000-2002-UAL & $\begin{array}{l}\text { Courses "Solar Architecture" and "Ecology" are introduced as courses } \\
\text { in the study programme Architecture }\end{array}$ \\
\hline 7 & $2007-\mathrm{FH}$ & $\begin{array}{l}\text { The course Good Governance is introduced in the study programme } \\
\text { Public Management }\end{array}$ \\
\hline 8 & 2008-JKU & The event series "Education for Sustainable Development" is initiated \\
\hline 9 & $2008-\mathrm{JKU}$ & Graduate Master Programme Energy Management is initiated \\
\hline 10 & 2010 - UAL & Endowment professorship for "Sustainability and Spatial Tactics" \\
\hline 11 & $2010-\mathrm{FH}$ & Event Series "Public Management Impulse" \\
\hline 12 & $2010-\mathrm{JKU}$ & $\begin{array}{l}\text { Event Series "Austrian Days of Environmental Law" at the Institute for } \\
\text { Environmental Law is awarded the Sustainability Award } 2010\end{array}$ \\
\hline 13 & $2012-\mathrm{JKU}$ & International conference on "European Environmental Law" \\
\hline 14 & $2014-\mathrm{PH}$ & Start of the Public Lecture series, targeting on socio-political topics \\
\hline 15 & $2015-\mathrm{JKU}$ & First international symposium on European Environmental Law \\
\hline 16 & 2015-JKU & $\begin{array}{l}\text { Participation of the Institute of Environmental Law in the Future Lec- } \\
\text { ture series }\end{array}$ \\
\hline
\end{tabular}

$J K U$ Johannes Kepler University Linz, KTU Catholic Theological Private Universiy, PH College of Education, UoAS University of Applied Sciences Upper Austria, UAL University of Arts Linz

\section{References}

Arbo P, Benneworth P (2007) Understanding the regional contribution of higher education institutions: A literature review. Education working paper, vol. 9. OECD Publishing, Paris. https://doi.org/10.1787/ 161208155312

Barlett PF (2008) Reason and reenchantment in cultural change: Sustainability in higher education. Curr Anthropol 49:1077-1098. https://doi.org/10.1086/592435

Benneworth P et al (2009) Exploring the multiple roles of Lund University in strengthening Scania's regional innovation system: Towards institutional learning? Eur Plan Stud 17(11):1645-1664. https:// doi.org/10.1080/09654310903230582

Austrian Federal Ministry of Science and Research (BMWF), Austrian Federal Ministry of Agriculture, Forestry, Environment and Water Management (BMLFUW) (ed) (2010) Sustainability Award 2010. Die eingereichten Projekte. BMWF, Wien.

Austrian Federal Ministry of Science and Research (BMWF), Austrian Federal Ministry of Agriculture, Forestry, Environment and Water Management (BMLFUW) (ed) (2012) Sustainability Award 2012. Die eingereichten Projekte. BMWF, Wien

Austrian Federal Ministry of Science and Research (BMWF), Austrian Federal Ministry of Agriculture, Forestry, Environment and Water Management (BMLFUW) (ed) (2014) Sustainability Award 2014. Die eingereichten Projekte. BMWF, Wien

Boschma R, Martin R (2010) The new paradigm of evolutionary economic geography. In: Boschma R, Martin R (eds) The Handbook of Evolutionary Economic Geography. Edward Elgar Publishing Limited, Cheltenham, pp 3-42 
Brown RR, Farrelly MA, Loorbach DA (2013) Actors working the institutions in sustainability transitions: The case of Melbourne's stormwater management. Glob Environ Chang 23:701-718

Campus Sustainability Center (2005) COPERNICUS guidelines for sustainable development in the European higher education area. How to incorporate the principles of sustainable development in the bologna process. http://media.ehea.info/file/COPERNICUS_Olderburg_2006/92/6/COPERNICUS Guidelines_587926.pdf. Accessed 3 Sept 2016

Catholic-Theological Private University Linz (2017) http://ku-linz.at. Accessed 23 Mar 2017

Chatterton P, Goddard J (2000) The response of higher education institutions to regional needs. Eur J Educ 35:475-496

Coenen L, Bennworth P, Truffer B (2012) Toward a spatial perspective on sustainability transition. Res Policy:968-979. https://doi.org/10.1016/j.respol.2012.02.014

College of Education Upper Austria (2017) https://ph-ooe.at/. Accessed 25.07.

Colyvas JA, Powell W (2007) Roads to institutionalization: The remaking of boundaries between public and private science. Res Organ Behav 27:305-353

Denman BD (2009) What is a university in the 21st century. High Educ Manag Policy 8(17):9-28

Eisen A, Bartlett P (2006) The Piedmont Project: Fostering faculty development toward sustainability. J Enviornmental Educ 38:25-36. https://doi.org/10.3200/JOEE.38.1.25-36

Energy Institute (2017) Project database of the energy institute at the JKU. http://www.energieinstitut-linz. at/v2/projekte/. Accessed 5 Feb 2017

European University Association (2005) Graz Declaration. Forward from Berlin: the role of universities. http://www.aic.lv/bolona/Bologna/maindoc/Graz\%20Decl.pdf. Accessed 5 Sept 2016

Fachhochschulstudiengesetz 1993 (2017) Fachhochschulstudiengesetz 1993 - Bundesgesetz über Fachhochschul-Studiengänge. https://www.ris.bka.gv.at/eli/bgbl/I/2017/129. Accessed 1 Aug 2017 (StF: BGB1. Nr. 340/1993, idF BGB1. I Nr. 129/2017)

Fritsch M, Slavtchev V (2010) How does industry specialization affect the efficiency of regional innovation systems? Ann Reg Sci 45:87-108

Geels FW, Deuten JJ (2006) Aggregation activities local and global dynamics in technological development: A socio-cognitive perspective on knowledge flows and lessons from reinforced concrete. Sci Public Policy 33:265-275

Genus A, Coles A (2008) Rethinking the multi-level perspective of technological transitions. Res Policy 37:1436-1445

Gibbs D (2006) Prospects for an environmental economic geography: Linking ecological modernization and regulationist approaches. Econ Geogr 82:193-215

Goddard J, Puukka J (2008) The engagement of higher educational institutions in regional development. An overview of the opportunities and challenges. Higher Education Management and Policy 20(2). OECD Publishing, Paris.

Goldstein H, Peer V, Sedlacek S (2016) The pathways and challenges of university engagement. Comparative Case Studies in Austria. MODUL University Working Paper No. 7. Available at SSRN: https:// ssrn.com/abstract=2876300

Gunasekara C (2006) Academia and industry. The generative and development roles of universities in regional innovation systems. Sci Public Policy 33(2):137-150

Hamann R, April K (2013) On the role and capabilities of collaborative intermediary organisations in urban sustainability transitions. J Clean Prod 50:12-21

Hansen T, Coenen L (2015) The geography of sustainability transitions: Review, synthesis and reflections on an emergent research field. Environ Innov Soc Transitions 17:92-109. https://doi.org/10.1016/j. eist.2014.11.001

Hochschulgesetz 2005 (2017) Bundesgesetz über die Organisation der Pädagogischen Hochschulen und ihre Studien. StF: BGB1. I Nr. 30/2006, idF BGB1. I Nr. 129/2017. https://www.ris.bka.gv.at/ GeltendeFassung.wxe?Abfrage=Bundesnormen\&amp;Gesetzesnummer=20004626. Accessed 1 Aug 2017

Hoover E, Harder MK (2015) What lies beneath the surface? The hidden complexities of organizational change for sustainability in higher education. J Clean Prod 106:175-188. https://doi.org/10.1016/j. jclepro.2014.01.081

Hord SM (1986) A synthesis of research on organizational collaboration. Educ Leadersh 43:22-26

Johannes Kepler University (JKU) Linz (2009) Development plan 2006-2012. http://www.jku.at/ifg/ content/e147790/e148003/Entwicklungsplan_Endfassung_MTB19_220409_ger.pdf. Accessed 2 Sept 2016 
Johannes Kepler University (JKU) Linz (2013) Development plan 2013-2018. http://www.jku.at/Rektorat/ content/e6424/e6366/e6295/e226968/JKU-Entwicklungsplan2013-18Stand04122013_ger.pdf. Accessed 4 Sept 2016

Johannes Kepler University Linz (JKU) (2017) http://www.jku.at. Accessed 27 Mar 2017

Johannes Kepler University Linz (JKU) (2017) Research documentation. http://www.jku.at/content/e263/ e16099/e16086/. Accessed 1 Feb 2017

Lozano R et al (2015) A review of commitment and implementation of sustainable development in higher education: results form a worldwide survey. J Clean Prod 108:1-18. https://doi.org/10.1016/j.jclepro. 2014.09.048

McCormick et al (2013) Advancing sustainable urban transformation. J Clean Prod 50:1-11. https://doi. org/10.1016/j.jclepro.2013.01.003

Murphy JT (2015) Human geography and socio-technical transition studies: Promising intersections. Environ Innov Soc Transitions 17:73-91. https://doi.org/10.1016/j.eist.2015.03.002

Olsen JP (2007) The institutional dynamics of the European university. In: Maasse P, Olsen JP (eds) University dynamics and European integration. Springer, Dordrecht, pp 25-54

Österreichischer Wissenschaftsrat (2016) Analyse der Leistungsvereinbarungen 2016-2018 und Empfehlungen. Österreichischer Wissenschaftsrat, Wien

Peer V, Penker M (2016) Higher education institutions and regional development: A meta-analysis. Int Reg Sci Rev 39(2):228-253

Peer V, Stoeglehner G (2013) Universities as change agents for sustainability e framing the role of knowledge transfer and generation in regional development processes. J Clean Prod 44:85-95. https://doi. org/10.1016/j.jclepro.2012.12.003

Privatuniversitätengesetz (PU) 2011 (2017) Bundesgesetz über Privatuniversitäten. StF: BGBl. I Nr. 74/ 2011, idF BGB1. I Nr. 129/2017. https://www.ris.bka.gv.at/GeltendeFassung.wxe?Abfrage=Bundes normen\&amp;Gesetzesnummer=20007385. Accessed 1 Aug 2017

Radinger-Peer et al (2015) Regional vulnerability to the challenges of climate change and energy provision: Lessons learned from transdisciplinary assessments in Austria and Germany. GAIA 24(4):261-270

Rohracher H, Späth P (2014) The Interplay of urban energy policy and socio-technical transitions: The eco-cities of Graz and Freiburg in retrospect. Urban Stud 51(7):1415-1431. https://doi.org/10.1177/ 0042098013500360

Russell AW et al (2008) Transdisciplinarity: Context, contradictions and capacity. Futures 40:460-472

Saxenian AL (2000) Networks of immigrant entrepreneurs. In: Lee CM, Miller WF, Hancock MG, Rowen HS (eds) The silicon valley edge: A habitat for innovation and entrepreneurship. Stanford University Press, Stanford, CA

Scott WR (2001) Institutions and organizations. SAGE, Thousand Oaks

Sedlacek S (2013) The role of universities in fostering sustainable development at the regional level. J Clean Prod 48:74-84. https://doi.org/10.1016/j.jclepro.2013.01.029

Shiri M, Breznitz M, Feldman P (2012) The engaged university. J Technol Transf :139-157. https://doi. org/10.1007/s10961-010-9183-6

Späth P, Rohracher H (2012) Local demonstrations for global transitions-dynamics across governance levels fostering socio-technical regime change towards sustainability. Eur Plan Stud 20:461-479

Stadtplanung Linz (2013) Örtliches Entwicklungskonzept Linz Nr. 2. Baulandkonzept. Gemeinderatsbeschluss 23 May 2013

Stephens JC et al (2008) Higher education as a change agent for sustainability in different cultures and contexts. Int J Sustain High Educ 9(3):317-338

Stephens JC, Graham AC (2010) Toward an empirical research agenda for sustainability in higher education: Exploring the transition management framework. J Clean Prod 18:611-618. https://doi.org/10. 1016/j.jclepro.2009.07.009

Strambach S (2010) Path dependence and path plasticity: The co-evolution of institutions and innovation in the German customized business software industry. In: Boschma R, Martin R (eds) The handbook of evolutionary economic geography. Edward Elgar Publishing Limited, Cheltenham, pp 406-431 https://doi.org/10.4337/9781849806497.00029

Strambach S, Halkier H (2013) Reconceptualizing change, path dependency, path plasticity and knowledge combination. Z Wirtschgeogr 57:1-14

Strambach S, Pflitsch G (2017) Micro-dynamics in regional transition paths to sustainability-insights from the Augsburg region. Appl Geogr. https://doi.org/https://doi.org/10.1016/j.apgeog.2017.04.012

Sustainability Transition Research Network (STRN) (2010) A mission statement and research agenda for the sustainability transitions research network. http://www.transitionsnetwork.org/. Accessed 20 Sept 2016 
Trippl M, Tödtling F (2013) Transformation of regional innovation systems: From old legacies to new development paths. In: Cooke P (ed) Reframing regional development. Routledge, London, pp 297-317

Truffer B, Coenen L (2012) Environmental innovation and sustainability transitions in regional studies. Reg Stud 46:1-21. https://doi.org/10.1080/003434

Uni:data (2016) Number of students and personnel of selected HEIs. https://oravm13.noc-science.at/apex/ $\mathrm{f}$ ? $\mathrm{p}=103: 6: 0::$ NO::P6_OPEN:N. Accessed 25 Aug 2016

University Law 2002 (2017) Bundesgesetz über die Organsiation der Universitäten udn ihre Studien. StF: BgBl. I Nr. 120/2002, idF BGBl. I Nr. 11/2017. https://www.ris.bka.gv.at/GeltendeFassung.wxe? Abfrage $=$ Bundesnormen $\&$ Gesetzesnummer $=20002128$. Accessed 15 Jan 2017

University of Applied Sciences Upper Austria Campus Linz (2016) Mission statement of the university of applied sciences upper Austria. https://www.fh-ooe.at/ueber-uns/vision-leitbild/strategie/. Accessed 12 Aug 2016

University of Applied Sciences Upper Austria Campus Linz (2017) Campus Linz. https://www.fh-ooe.at/ campus-linz/. Accessed 14 Mar 2017

University of Applied Sciences Upper Austria Campus Linz (2017) Research documentation. http:// research.fh-ooe.at/. Accessed 2 Feb 2017

University of Arts and Industrial Design Linz (2014) Development Plan 2014-2018. https://ufgonline.ufg. ac.at/ufg_online/wbMitteilungsblaetter.display?pNr=87821. Accessed 21 Mar 2017

University of Arts and Industrial Design Linz (2017) http://www.ufg.ac.at/. Accessed 21 Mar 2017

University of Arts and Industrial Design Linz (2017) Research documentation. https://ufgonline.ufg.ac.at/ ufg_online/webnav.ini. Accessed 2 Feb 2017

Wickson $\mathrm{F}$ et al (2006) Transdisciplinary research: Characteristics, quandaries and quality. Futures 38:1046-1059. https://doi.org/10.1016/j.futures.2006.02.011

Wissenschaftlicher Beirat der Bundesregierung globale Umweltveränderungen (WBGU) (2011) Hauptgutachten. Welt im Wandel Gesellschaftsvertrag für eine Große Transformation. Zusammenfassung für Entscheidungsträger. WBGU, Berlin.

World Commission on Environment and Development (WCED) (1987) Our common future. http://www. un-documents.net/our-common-future.pdf. Accessed 15.2016

Wright T, Wilton H (2012) Facilities management directors' conceptualizations of sustainability in higher education. J Clean Prod 31:118-125. https://doi.org/10.1016/j.jclepro.2012.02.030 